decrease in diastolic pressure had no relation to the initial level. The magnitude of the drop in systolic pressure, however, was highly related $(p<0.01)$ to the initial value.

\section{Discussion}

Most of the information about follow-up measurements in untreated patients with hypertension has come from the control groups of intervention trials. In all of these trials both systolic and diastolic pressures fell at subsequent measurements. It has been difficult to follow up this phenomenon, however, because subjects drop out, which may bias the remaining group. The Australian mild hypertension trial reported the follow-up blood pressures of 1119 of their patients who continued their regimen for at least three years. ${ }^{3}$ This group sustained continuing falls in systolic and diastolic pressures until the fourth visit. The first two appointments, however, were screening visits that did not take place at the clinic where subsequent measurements were made; presumably the observers changed as well. Placebo treatment was also begun at the third follow up visit, which may have induced a further fall.

While such studies have clearly documented the phenomenon they have not been designed to study it specifically. Dunne investigated 20 outpatients referred for evaluation of raised blood pressure. ${ }^{5}$ He measured their blood pressures fortnightly for three visits and found appreciable falls only from the first to second visit in both systolic and diastolic pressures. As all his patients were on the same schedule of visits, he could not comment on the importance of the timing of follow-up appointments on the observed fall in pressure.

Our study was designed to investigate the relative contributions of the number of visits and their timing to the fall in systolic and diastolic pressures. The results show that in a group of patients who were identified and followed up by their own doctor systolic pressure fell between the first and second (first follow-up) visit and fell again appreciably between the second and third visit. Though the same trend is evident for diastolic pressures the fall is only statistically significant to the second visit. The timing of these subsequent measurements does not affect the fall, although the measurements must occur at separate visits.

These results provide a practical guide to observing patients who are newly identified as having mildly raised blood pressure. We thus recommend that patients are seen at two further visits before a decision is made about treatment. The timing of the visits is not crucial, but to conform with the period of observation in our study the follow-up visit should occur within two months of the first measurement, and visits should be at least one week apart. Patients who do not start treatment should be periodically rechecked.

We thank the many general practitioners who participated in this study and the Scottish Home and Health Department for financial assistance.

\section{References}

${ }^{1}$ Beevers DG. Blood pressures that fall on rechecking. Br Med $\mathcal{F} 1982 ; 284$ : $71-2$.

2 Miall WE, Brennan PJ. In: Gross F, Strasser T, eds. Mild hypertension: natural history and management. London: Pitman Medical, 1979:38-46.

${ }^{3}$ Management Committee of Australian Therapeutic Trial in Mild Hypertension. Untreated mild hypertension. Lancet $1982 ; \mathrm{i}: 185-91$.

* Medical Research Council Working Party on Mild to Moderate Hypertension. Randomised controlled trial of treatment for mild hypertension: design and pilot trial. $\mathrm{Br}$ Med $\mathcal{F} 1977 ; \mathrm{i}: 1437-40$.

${ }^{5}$ Dunne JF. Variation of blood-pressure in untreated hypertensive outpatients. Lancet 1969;i:391-2.

\title{
Identification of adverse reactions to new drugs. II-How were 18 important adverse reactions discovered and with what delays?
}

\author{
GEOFFREY R VENNING
}

\begin{abstract}
The process of discovery of 18 important adverse drug reactions was reviewed. For each adverse reaction the dates were noted of the report which first alerted the medical profession to the suspected reaction, the report which resulted in verification of causality beyond reasonable doubt, and the first regulatory action or warning to the medical profession in Britain by the Committee on the Safety of Medicines.
\end{abstract}

\section{Introduction}

In part I (published last week, p 199) 18 important adverse

\footnotetext{
University Department of Community Medicine and General Practice, Oxford

GEOFFREY R VENNING, BM, FRCP, visiting scientist (now director of research and development, Janssen Pharmaceutical Limited, Marlow, Bucks SL7 1ET)
}

reactions to 15 drugs or drug groups were identified by physicians who were unaware of the purpose for which the list would be used. This constituted an unbiased list (see table) for a study of the process whereby serious reactions to drugs had been discovered in recent years. In view of the separate problems encountered in the discovery of different types of reactions I have attempted (table) to classify each adverse reaction according to the method of Rawlins and Thompson. ${ }^{1}$ They defined reactions based on known pharmacology as type $\mathrm{A}$; these are usually predictable, relatively frequent, and seldom fatal. Unpredictable, idiosyncratic reactions including many that are mediated by immunological mechanisms are defined as type B and are usually infrequent but can be very serious or fatal.

\section{Method}

In reviewing published work on these adverse reactions an attempt was made to find the first report or regulatory warning for identification of the alerting mechanism. To assess the verification process for each adverse reaction emphasis was placed on careful evaluation of subsequent reports in chronological order. Each was scrutinised for evidence which would have convinced the author of causality, the criterion chosen for the level of verification being less than absolute proof but 
Important adverse reactions selected for review of discovery process

\begin{tabular}{|c|c|c|}
\hline Adverse reaction & Type* & Drug \\
\hline $\begin{array}{l}\text { (1) Dermatitis } \\
\text { (2) Keratoconjunctivitis } \\
\text { (3) Sclerosing peritonitis } \\
\text { (4) Thromboembolism } \\
\text { (5) Myocardial infarction } \\
\text { (6) Nephropathy } \\
\text { (7) Lactic acidosis } \\
\text { (8) Deaths from asthma } \\
\text { (9) Subacute myelooptic neuropathy } \\
\text { (10) Vaginal cancer (in daughters) } \\
\text { (11) Aplastic anaemia } \\
\text { (12) Jaundice } \\
\text { (13) Retroperitoneal fibrosis } \\
\text { (14) Pseudomembranous colitis } \\
\text { (15) Pseudomembranous colitis } \\
\text { (16) Pseudomembranous colitis } \\
\text { (17) Aplastic anaemia } \\
\text { (18) Tardive dyskinesia }\end{array}$ & $\begin{array}{l}\text { B } \\
\text { B } \\
\text { B } \\
\text { B } \\
\text { B } \\
\text { B } \\
\text { A } \\
\text { B } \\
\text { B } \\
\text { A } \\
\text { B } \\
\text { B } \\
\text { B } \\
\text { B } \\
\text { B } \\
\text { B } \\
\text { B } \\
\text { A }\end{array}$ & $\begin{array}{l}\text { Practolol } \\
\text { Practolol } \\
\text { Practolol } \\
\text { Oral contraceptives } \\
\text { Oral contraceptives } \\
\text { Analgesics (especially phenacetin) } \\
\text { Phenformin } \\
\text { Sympathomimetic aerosols } \\
\text { Clioquinol } \\
\text { Stilboestrol (maternal) } \\
\text { Chloramphenicol } \\
\text { Halothane } \\
\text { Methysergide } \\
\text { Tetracycline etc } \\
\text { Lincomycin } \\
\text { Clindamycin } \\
\text { Phenylbutazone } \\
\text { Phenothiazines }\end{array}$ \\
\hline
\end{tabular}

*Rawlins and Thompson's classification.'

enough to leave no reasonable doubt or to be an adequate basis for regulatory action should this be applicable.

To avoid overlooking key publications or other reports manufacturers were asked to comment on the discovery processes. Manufacturers also gave the dates of marketing for their products. Finally, any regulatory action in the United Kingdom was noted when this occurred.

\section{Results}

(1-3) OCULOMUCOCUTANEOUS SYNDROME DUE TO PRACTOLOL-DRUG MARKETED 1970; UK REGULATORY WARNING 1975; DRUG WITHDRAWN 1976

Recognition of the three components of the oculomucocutaneous syndrome occurred separately.

\section{(1) Dermatitis}

Alerting-After two years Rowland and Stevenson ${ }^{2}$ reported exfoliative dermatitis in a patient receiving many drugs to which practolol had been added; the rash cleared on stopping practolol and continuing the other drugs.

Verification-After a further two years Felix and Comaish ${ }^{3}$ established the causal role of practolol by patch testing in one patient and intradermal skin testing and response to rechallenge in another.

\section{(2) Keratoconjunctivitis}

Alerting-After four years Wright ${ }^{4}$ noted atypical features of the keratoconjunctival lesions in patients with practolol skin eruptions"unlike the conjunctival scarring seen in association with ..." (other skin eruptions).

Verification-Within another year (five years from introduction) Felix et $a l^{5}$ had noted that three out of 21 patients with practolol dermatitis had associated keratoconjunctivitis, and Wright ${ }^{6}$ reported 27 patients with eye lesions, of whom 19 had associated skin lesions.

\section{Comment}

Failure to record adverse events ${ }^{78}$ as distinct from suspected adverse reactions during the clinical trials caused a delay in recognising the problem, as was clearly established by a later study ${ }^{9}$ of 71 patients with full event recording during practolol use and a period of the same duration before treatment. There was a significant increase in eye complaints during practolol treatment $(20 \% v 6 \%$ for all eye complaints $(\mathrm{p}=0.006)$, and $7 \% v 3 \%$ for conjunctival or corneal signs). Using patients as their own controls in this manner is an important design feature for the early identification of adverse reactions to drugs in clinical trials. Event recording without such a control period might not have been enough; this was not emphasised in the paper by the same authors on the case for recording events in clinical trials. ${ }^{8}$ Recognising the minor forms of the adverse reactions, which are relatively common, might have played an important part in alerting to the less frequent but more serious form.

\section{(3) Sclerosing peritonitis}

Alerting-Four years after practolol was first marketed Brown et al ${ }^{10}$ reported three cases of sclerosing peritonitis and the company received additional reports in response to a letter requesting information on adverse reactions to the drug as a result of the ocular problem. In view of the unusual nature of the lesion the reports were good evidence.

Verification came from further reports over the next two years, including 16 cases from one area reported by Marshall et al, ${ }^{11}$ and 50 reports on yellow cards to the Committee on the Safety of Medicines.

Comment-The time to recognition was reasonable given that prolonged exposure is required before peritonitis develops. The incidence of this adverse reaction in long term users is unknown, so that it is not possible to assess the size of cohort that would have been needed to identify the problem in a recorded-release study or the duration of study that would have been required.

(4) THROMBOEMBOLISM DUE TO ORAL CONTRACEPTIVES-DRUGS MARKETED 1958; UK REGULATORY WARNING 1969

(In the United States the first oral contraceptive, Enovid, was at first promoted only as a drug for gynaecological indications, and the spread of its use as an oral contraceptive developed gradually during the next few years. In Britain the introduction of oral contraception can be dated more precisely to 1963 , when the same drug was introduced, for this indication only, with the name Conovid.)

Alerting-Three years after first marketing in the United States Jordan ${ }^{12}$ reported pulmonary embolism without precipitating cause in a young woman treated with Enavid (British spelling) for endometriosis. Though uncommon, the condition may occur naturally and further anecdotal reports did not resolve the problem.

Verification-Six years later the Medical Research Council ${ }^{13}$ showed increased frequency of use of oral contraceptives in three case-contro studies of deaths from pulmonary embolism and of thromboembolic disease resulting in admission to hospital and occurring in general practice.

Comment-The result of the mortality study was particularly strong evidence; nevertheless, this was less than proof of causality, which required and received confirmation from prospective studies and from further case-control studies with demonstration of dose dependence. As the incidence of pulmonary embolism is about 1 in 20000 a cohort approach to postmarketing surveillance with a sample size of 10000 would have been unlikely to lead to alerting to this problem. Assessing the frequency of thrombosis without embolism is less reliable because of diagnostic imprecision.

(5) MYOCARDIAL INFARCTION DUE TO ORAL CONTRACEPTIVES-DRUGS MARKETED 1958; NO REGULATORY WARNING IN UK

Alerting-Myocardial infarction was first reported in 1963, five years after introduction, by Boyce et al. ${ }^{14}$ Their anecdote was very weak evidence, even with further similar reports which followed, until Inman and Vessey ${ }^{15}$ reported a case-control study of deaths from various forms of thrombosis and embolism. They found an excess of users of oral contraceptives among women who had died of myocardial infarction, which was significant only in the subset of deaths with no predisposing cause.

Verification - Two years later Inman et al ${ }^{16}$ showed a significant dose relation in a study of the frequency of reports of myocardial infarction to the drug safety committee in relation to sales of products containing different doses of oestrogen.

Comment-Although the dose-response data constituted reasonable verification, this was not generally accepted until supported by further case-control studies ${ }^{17}{ }^{18}$; subsequently a prospective study ${ }^{19}$ provided further confirmation. With an incidence of about 1 in 10000 a cohor approach would again have been ineffective for alerting or for verification, unless very large and combined with control data.

(6) ANALGESIC NEPHROPATHY DUE TO PHENACETIN (CHRONIC USAGE)-DRUG MARKETED 1887; FIRST REGULATORY WARNING 1974; SUBSEQUENT WARNING 1977; PRODUCTS BANNED 1980

Alerting-In 1953 Spuhler and Zollinger, ${ }^{20}$ investigating an apparent increase in frequency of chronic interstitial nephritis, reviewed case records of patients with particular renal histologica lesions. Of 43 patients, 13 were noted to be regular users of analgesics containing phenacetin. The possibility was considered that they might

(1)


have used analgesics for headache associated with renal failure. Despite this there were good grounds for further study.

Verification-Further reports were published over the next six years but proof came from a cross sectional study by Larsen and Moller. ${ }^{21}$ They reviewed 698 hospital inpatients and established a significant correlation between impaired renal function and the dosage and duration of phenacetin use, with a prevalence of renal failure of $80^{\prime \prime}$ " in patients using $1 \mathrm{~g}$ daily for 10 years.

Comment-The extent, if any, of delay in alerting to this adverse reaction cannot be assessed. Though overall usage of phenacetin increased after the second world war, ${ }^{22}$ information is lacking on the extent of prolonged usage of phenacetin in the previous half century. The delay between alerting and verification was substantial. The overall incidence was extremely low in relation to the widespread use of phenacetin. A cohort approach would have been ineffective for alerting or verification and impracticable in relation to the problem of drug abuse.

(7) LACTIC ACIDOSIS DUE TO PHENFORMIN-DRUG MARKETED 1969; UK REGULATORY WARNING 1980

Alerting-Ten years before marketing, Walker and Linton ${ }^{23}$ had conducted clinical trials of phenformin in diabetes and noted ketosis not responsive to insulin. They showed that this was due to lactic acidosis, which was a consistent effect of the drug after exercise and was occasionally severe and fatal.

Verification was not needed, as proof was established.

Comment-The key role of individual skill and of experimental evidence is emphasised. A high standard of medical and scientific expertise and vigilance in the clinical trial stage may be expected to result in early identification of adverse reactions based on pharmacological activity.

(8) DEATHS FROM ASTHMA DUE TO SYMPATHOMIMETIC AEROSOLSDRUGS MARKETED 1961; UK REGULATORY WARNING 1967

Alerting-After four years the Australian Drug Evaluation Committee $^{24}$ reported five deaths after overdosage of sympathomimetic drugs and considered that metered-dose aerosols were a particular cause of cardiac deaths. One year later Greenberg and Pines ${ }^{25}$ reported eight deaths associated with excessive aerosol use in England, and B Corner reported an increase in deaths from asthma in childhood in the Bristol area (paper presented to joint meeting of British Tuberculosis Association and West of England Thoracic Society, Bristol, 1 April 1966). This was then found to apply also to England and Wales. ${ }^{26}$ The deaths were not specifically cardiac.

Verification-Epidemiological studies by Speizer et $a l^{27}$ indicated that the increase was real and that aerosols might be responsible. ${ }^{28}$ Evidence was subsequently advanced in support from a fall in mortality after publicity and reduced use of high-dose aerosols. ${ }^{29}$ Other changes in asthma treatment during the period make evaluation difficult, and the precise pathogenesis of the increase which occurred in childhood mortality is still incompletely understood.

Comment-Although the evidence is very strong it was disputed on the grounds that in some countries there was no problem; this discrepancy has been satisfactorily explained on the basis of sales of particular highly concentrated nebulisers. ${ }^{30}$ The incidence was very low and a cohort approach to postmarketing surveillance would almost certainly have been of no help in alerting or verification.

(9) SUBACUTE MYELOOPTIC NEUROPATHY DUE TO CLIOQUINOLDRUG MARKETED 1935 (IN JAPAN); JAPANESE BAN ON SALES 1970

Alerting-The date of first alerting is not clear. The Japanese Government initiated inquiries into the problem before the first publication by $\mathrm{T}_{\text {subaki }}{ }^{31}$ in 1971 , who suggested that clioquinol was responsible for subacute myelooptic neuropathy, a syndrome of neurological disorder preceded by diarrhoea. The syndrome was first described in $1965^{32}$ after a decade during which an increase in incidence of "myelitis" had been noted in Japan. The reality of the increase has not been disputed, and the need for scrutiny of evidence suggesting clioquinol as a causal factor was clear.

Verification largely consisted in accumulating hospital records of patients with the diagnosis of subacute myelooptic neuropathy together with information about their use of clioquinol throughout Japan and by regions. The data were obtained and studied by a research commission studying the syndrome appointed by the Japanese health authorities in 1969. Clioquinol sales were banned as a result in September 1970, and the evidence was reported by Shigematsu. ${ }^{33}$

Comment - The validity of epidemiological arguments that clioquinol was responsible was challenged by Meade, ${ }^{34}$ and a very serious criticism was that of Pallis, ${ }^{35}$ who challenged the neurological criteria used for diagnosing the cases on which the epidemiological surveys were based. With the wisdom of hindsight, and experience from other countries, it seems likely that clioquinol can occasionally (but very rarely) produce neurological toxicity in man, but that the epidemic of subacute myelooptic neuropathy in Japan was not due solely or possibly even mainly to clioquinol. Nevertheless, it must be recognised that circumstances may exist in which it is in the public interest to take regulatory action against a drug even in the absence of proof of causality. It could be argued that such circumstances existed in Japan. There is no satisfactory evidence concerning the incidence of the adverse reaction, but this was almost certainly too low for a cohort approach to postmarketing surveillance to be effective for either alerting or verification.

(10) VAGINAL CARCINOMA DUE TO STILBOESTROL (MATERNAL ADMINISTRATION)-DRUG MARKETED 1948; NO REGULATORY WARNING IN UK

Alerting-After 22 years Herbst and Scully ${ }^{36}$ noted the occurrence of vaginal carcinoma with unusual histological features in six young women and did a case-control study to identify antecedent factors.

Verification-Within one year Herbst $e^{2} a^{37}$ showed that seven out of eight cases of vaginal carcinoma occurred in the daughters of mothers who had received stilboestrol during pregnancy. There was no such history for 32 matched controls, selected on the basis of four per case, from girls born within five days on the same obstetric service. Probability of chance occurrence was $p<0.00001$. Confirmation came from Herbst $e t a l^{38}$ in a review of a larger number of cases reported to a special registry. Maternal exposure was noted in 49 out of 66 cases of clear-cell cancers of the genital tract in the age group 8-25 years.

Comment-The interval between first marketing of stilboestrol and widespread use in pregnancy is not known; the alerting was due to individual skill in clinical observation, and verification came promptly from a case-control study. The incidence has been assessed as 1 in 1000 , so that a cohort of 10000 patients would have been needed for detection, with long term follow up of the children into adult life. This contrasts with the actual long term follow up of 70 children and 66 controls by Beral and Colwell, ${ }^{39}$ which identified other, more frequent but less serious reactions.

\section{(11) APLASTIC ANAEMIA DUE TO CHLORAMPHENICOL-DRUG} MARKETED 1949; UK REGULATORY WARNING 1967

Alerting-Smadel ${ }^{40}$ predicted bone marrow toxicity on the basis of the nitrobenzene component of the molecule. Arrest of maturation in the red-cell series in patients with leucopenia ${ }^{41}$ and later a case of aplastic anaemia ${ }^{42}$ were reported within one year.

Verification-Numerous cases were reported after a gap of another year ${ }^{43}$ and the United States Food and Drug Administration set up a nationwide survey and immediately identified 200 new cases. ${ }^{44}$ Epidemiological confirmation was hardly necessary in view of the rarity of idiopathic aplastic anaemia. (Further confirmation of causality came when Krakoff et $a l^{45}$ showed that reversible marrow suppression could be induced consistently by high dosage.)

Comment-The three year delay in general recognition of this problem led the American Medical Association to set up a blood dyscrasia registry, which is, unfortunately, no longer in operation. The incidence has been estimated as 1 in 20000 to 1 in 40000 . A cohort approach to postmarketing surveillance would have been of no help.

(12) JAUNDICE DUE TO HALOTHANE-DRUG MARKETED 1956; NO REGULATORY WARNING IN UK

Alerting-After two years Burnap et $a l^{46}$ reported two cases of postoperative hepatic failure after halothane but other contributory factors existed. After another five years there were two reports by 
Deacon $^{47}$ and Tygstrup ${ }^{48}$ of patients who received halothane on three occasions, with no complications after the first exposure but jaundice after the second and third anaesthetics. These raised the question of sensitisation, now known to be critical.

Verification-The American National Halothane Study, ${ }^{49}$ which analysed retrospectively data from a quarter of a million halothane anaesthetics and 600000 other anaesthetics, showed no general problem but a small excess of halothane compared with other anaesthetics among patients developing jaundice after repeated exposures. Proof was obtained 13 years after introduction, when Klatskin and Kimberg ${ }^{50}$ reported the case of an anaesthetist who developed jaundice seven times in five years each time he was exposed to halothane at work, with remission each time exposure was stopped. (This 1969 evidence satisfied the author; others have suggested that critical verification was not provided until 1975 , when Trowell et al ${ }^{51}$ showed in a randomised trial that patients receiving repeated halothane anaesthetics for radium treatment of cancer of the uterine cervix had a significantly higher incidence of liver function abnormalities than controls receiving repeated anaesthesia without halothane or methoxyflurane.)

Comment - This shows the strength of small controlled experiments and of scientific search for specific factors in adverse drug reactions and the weakness of a large expensive study without randomisation. It is another example of an adverse reaction that could not be identified by a cohort approach, even when much larger than any proposed recorded-release schemes.

(13) RETROPERITONEAL FIBROSIS DUE TO METHYSERGIDE-DRUG MARKETED 1960; NO REGULATORY WARNING IN UK

Alerting-After four years Graham $^{52}$ reported two cases among 500 patients treated. (This was published three years after the adverse reactions occurred.)

Verification-Within another two years Graham et al ${ }^{53}$ reviewed eight further cases of their own and 17 from other workers.

Comment-In view of the extreme rarity of retroperitoneal fibrosis in the absence of methysergide, the reports were virtual proof of causality. In assessing the time taken for recognition it should be noted that this adverse reaction occurs only after prolonged drug treatment -from nine months to over four years. A cohort approach might have been effective in identifying the reaction but long term follow up would have been necessary - a feature not present in most proposals for recorded release. The incidence is not known, as it may be less than noted by Graham, and the size of cohort that would have been required cannot be stated.

Next week's article will continue to examine how the 18 adverse reactions were discovered and with what delays.

\section{References}

${ }^{1}$ Rawlins MD, Thompson JW. Pathogenesis of adverse drug reactions. In: Davies DM, ed. Textbook of adverse drug reactions. Oxford: Oxford University Press, 1977.

Rowland MGM, Stevenson CJ. Exfoliative dermatitis and practolol Lancet $1972 ; \mathrm{i}: 1130$.

${ }^{3}$ Felix RH, Comaish JS. The value of patch and other skin tests in drug eruptions. Lancet $1974 ;$ i:1017-9.

4 Wright P. Skin reactions to practolol. Br Med f 1974;ii:560.

${ }^{5}$ Felix RH, Ive FA, Dahl MGC. Cutaneous and ocular reactions to practolol. Br Med f 1974 ;iv:321-4.

6 Wright P. Untoward effects associated with practolol administration oculomucocutaneous syndrome. $\mathrm{Br} \mathrm{Med} \mathcal{F}$ 1975; ; :595-8.

Finney DJ. The design and logic of a monitor of drug use. $\mathcal{f}$ Chronic Dis $1965 ; 18: 77-98$

"Skegg DCG, Doll $\mathbf{R}$. The case for recording events in clinical trials. Br Med F 1977; ii:1523-4.

${ }^{9}$ Skegg DCG, Doll R. Frequency of eye complaints and rashes among patients receiving practolol and propranolol. Lancet 1977;ii:475-8.

${ }^{10}$ Brown P, Baddeley H, Read AE, Davies JD, McGarry J. Sclerosing peritonitis, an unusual reaction to a $\beta$-adrenergic-blocking drug (practolol). Lancet 1974; ii:1477-81.

${ }^{11}$ Marshall AJ, Baddeley H, Barritt DW, et al. Practolol peritonitis. Qf Med $1977 ; 46: 135-49$.

12 Jordan WM. Pulmonary embolism. Lancet 1961 ;ii :1146-7.

13 Medical Research Council. Risk of thromboembolic disease in women taking oral contraceptives. Br Med $\mathcal{f} 1967$;ii:355-9.

${ }^{14}$ Boyce J, Fawcett JW, Noall EWP. Coronary thrombosis and Conovid. Lancet $1963 ; \mathrm{i}: 111$.

15 Inman WHW, Vessey MP. Investigation of deaths from pulmonary, coronary, and cerebral thrombosis and embolism in women of childbearing age. Br Med f 1968;ii:193-9.

${ }^{16}$ Inman WHW, Vessey MP, Westerholm B, Engelund A. Thromboembolic disease and the steroidal content of oral contraceptives; a report to the Committee on Safety of Drugs. Br Med F 1970;ii :203-9.

17 Mann JI, Vessey MP, Thorogood M, Doll R. Myocardial infarction in young women with special reference to oral contraceptive practice. Br Med f 1975;ii :241-5.

18 Mann JI, Inman WHW. Oral contraceptives and death from myocardial infarction. Br Med f 1975 ;ii:245-8.

19 Royal College of General Practitioners. Mortality among oral contraceptive users. Lancet $1977 ;$ ii:727-31.

${ }^{20}$ Spuhler O, Zollinger HU. Die chronisch-interstitielle Nephritis. Zeitschrift für klinische Medizin 1953;151:1.

${ }^{21}$ Larsen K, Moller CE. A renal lesion caused by abuse of phenacetin. Act Med Scand 1959;164:53-71.

${ }^{22}$ Schweingruber R. Probleme de chronischen vergiftung mit kombinierten phenacetinpraparaten. Schweiz Med Wochenschr 1955;85:1162.

23 Walker RS, Linton AL. Phenethyl diguanide: a dangerous side-effect. $\mathrm{Br} \mathrm{Med} \mathrm{F} \mathrm{1959;ii:1005.}$

${ }^{24}$ Australian Drug Evaluation Committee. Sympathomimetic drugs and bronchial asthma. Med F Aust 1965;i:93-4

25 Greenberg MJ, Pines A. Pressurised aerosols in asthma. Br Med $\mathcal{f} 1967$; i : 563 .

${ }^{26}$ Smith JM. Death from asthma. Lancet 1966;i:1042.

27 Speizer FE, Doll R, Heaf P. Observations on recent increases in mortality from asthma. $\mathrm{Br}$ Med $\mathcal{F} 1968 ; \mathrm{i}: 335-9$.

28 Speizer FE, Doll R, Heaf P, Strang LB. Investigations into use of drug preceding deaths from asthma. Br Med f 1968;i:339-43.

${ }^{29}$ Inman WHW, Adelstein AM. Rise and fall of asthma mortality in England and Wales in relation to the use of pressurised aerosols. Lancet 1969;ii 279-85.

${ }^{30}$ Stolley PD. Why the United States was spared an epidemic of deaths due to asthma. Am Rev Respir Dis 1972;105:883-90.

${ }^{31}$ Tsubaki T. Neurological syndrome associated with clioquinol. Lance $1971 ; \mathrm{i}: 696-7$

32 Tsubaki T, Toyokura T, Tsukagoshi H. Subacute myelo-optico-neuropathy following abdominal symptoms-a clinical and pathological study. Fapanese fournal of Medicine 1965;4:181.

${ }^{33}$ Shigematsu I. A review of epidemiological studies of $S M() N$, in Epidemiological issues in reported drug induced illnesses. Hamilton, Ontario: McMaster University Library Press, 1978:167-71.

${ }^{34}$ Meade TW. Subacute myelo-optic neuropathy and clioquinol. An epidemiological case history for diagnosis. British fournal of Preventive and Social Medicine 1975;29:157-69.

35 Pallis C. Observations on the differential diagnosis of SMON, in Epidemiological issues in reported drug induced illnesses. Hamilton, Ontario: McMaster University Library Press, 1978:152-62.

${ }^{36}$ Herbst AL, Scully RE. Adenocarcinoma of the vagina in adolescence. A report of seven cases including 6 clear cell carcinomas (so called mesonephromas). Cancer 1970;25:745-57.

${ }^{37}$ Herbst AL, Ulfelder H, Poskanzer DC. Adenocarcinoma of the vagina. Association of maternal stilboestrol therapy with tumor appearance in young women. $N$ Engl f Med $1971 ; 284: 878-81$.

${ }^{38}$ Herbst AL, Kurman RJ, Scully RE, Poskanzer DC. Clear-cell adenocarcinoma of the genital tract in young females. Registry report. $N$ Engl f Med 1972;287:1259-64.

${ }^{39}$ Beral V, Colwell L. Randomised trial of high doses of stilboestrol and ethisterone therapy in pregnancy: long-term follow-up of the children. f Epidemiol Community Health $1981 ; 35: 155-60$

${ }^{40}$ Smadel JE. Chloramphenicol (Chloromycetin) in the treatment of infectious diseases. Am 7 Med 1949;7:67.

${ }^{41}$ Volini IF, Greenspan I, Ehrlich L, Gonner JA, Felsenfeld O, Schwart SO. Hemopoietic changes during administration of chloramphenicol (Chloromycetin). $7 A M A$ 1950;142:1333-5.

${ }^{42}$ Rich ML, Ritterhof RJ, Hoffmann RJ. A fatal case of aplastic anemia following chloramphenicol (Chloromycetin) therapy. Ann Intern Med $1950 ; 33: 1459-67$.

43 Anonymous. Danger of chloramphenicol. Br Med f 1952 ;ii:136-8.

44 Anonymous. Is chloramphenicol dangerous? Br Med f 1952;ii:103.

45 Krakoff IH, Karnofsky DA, Burchenal JH. Effects of large doses of chloramphenicol on human subjects. $N$ Engl F Med 1975;253:7-10.

${ }^{46}$ Burnap TK, Galla SJ, Vandam LD. Anesthetic, circulatory and respiratory effects of Fluothane. Anesthesiology 1958;19:307-20.

${ }^{47}$ Deacon AL. Liver damage after halothane. Br Med f 1963;ii :56-7.

48 Tygstrup N. Halothane hepatitis. Lancet 1963;ii:466-7.

49 National Halothane Study. Possible association between halothan anesthesia and postoperative hepatic necrosis. $\mathcal{F} A M A$ 1966;197:775-808.

${ }^{50}$ Klatskin G, Kimberg DV. Recurrent hepatitis attributable to halothan sensitisation in an anesthetist. $N$ Engl f Med 1969;280:515-22.

51 Trowell J, Peto $R$, Crampton Smith A. Controlled trial of repeated halothane anaesthetics in patients with carcinoma of the uterine cervix treated with radium. Lancet $1975 ; \mathrm{i}: 821-3$.

${ }^{52}$ Graham JR. Methysergide for prevention of headache. Experience in five hundred patients over three years. $N$ Engl f Med 1964;270:67-72.

53 Graham JR, Subj HI, Le Compte PR, Sadowsky NL. Fibrotic disorder associated with methysergide therapy for headache. $N$ Engl $\mathcal{f} \mathrm{Med}$ $1966 ; 274: 359-68$.

(Accepted 11 November 1982) 